\title{
Perencanaan dan Perancangan Pusat Perbelanjaan di Kota Padang
}

\section{Shopping Center Planning and Design in the city of Padang}

\author{
* Eri Muslimin), Irnawati Siregar ${ }^{2)}$ \& Suwita3)
}

1)Mahasiswa Prodi Arsitektur Fakultas Teknik Dan Perencana Universitas Ekasakti, Indonesia 2,3) Dosen Prodi Arsitektur Fakultas Teknik Dan Perencana Universitas Ekasakti, Indonesia

Diterima: Februari 2020; Disetujui: April 2020; Dipublikasi: 30 April 2020

*Corresponding author: E-mail @ muslimeri30@gmail.com

\begin{abstract}
Abstrak
Perencanaan ini bertujuan untuk mengembangkan konsep pusat perbelanjaan yang sudah ada menjadi sebuah pusat perbelanjaaan yang memenuhi kebutuhan masyarakat baik dari segi kebutuhan berbelanja dan kebutuhan refresing bagi masyarakat dengan tema green building. Tujuan penelitan menciptakan wadah akomodasi berupa pusat perbelanjaan dengan area rekreasi yang lebih luas dan memadai bagi masyarakat Kota Padang. Metode penelitian dari perencanaan ini menggunakan metode kualitatif dengan menggunakan deskriptif secara rinci sesuai dengan kebutuhan penelitian. Lokasi Penelitian adalah kawasan Kuranji dengan luas $3 \mathrm{Ha}$, Kota Padang. Hasil perencanaan dari penelitian ini berupa sebuah pusat perbelanjaaan di Kota Padang dengan tema Green Building.

Kata Kunci : Perencanaan pusat perbelanjaaan
\end{abstract}

\begin{abstract}
This plan aims to develop the concept of an existing shopping center into a shopping center that meets the needs of the community both in terms of shopping needs and refresing needs for the community with the theme of green building. The purpose of this research is to create an acommodation container in the form of a shopping center with wider and adequete recreation area for the people of Padang City. The research method of this plan uses qualitative methods by using descriptive in detail according to research needs. The Reseacrh location is the Kuranji area with an area of $3 \mathrm{Ha}$, In Padang City. The planning results of this research are in the form of a shopping center in Padang with the theme Green Building.

Keywords: Shopping center planning
\end{abstract}

How to Cite : M. Eri, Irnawati S, Suwita , (2020), Perencanaan dan Perancangan Pusat Perbelanjaan di Kota Padang, Journal of Architecture and Urbanism Research, 3 (2): Hal 116-123 


\section{PENDAHULUAN}

Sumatera Barat merupakan salah satu Provinsi di Indonesia yang perekonomiannya terus meningkat, terutama di sektor perdagangan dan jasa. Peningkatan ini mampu melirik investor dalam negeri mau pun luar negeri yang hendak berinvestasi kususnya di sektor perniagaan dan jasa.

Pertumbuhan pembangunan yang di gerakan di segala bidang di Kota Padang telah mengikuti pertumbuhan penduduk, hal ini dapat di lihat dari lajunya pertumbuhan ekonomi yang semakin membaik yaitu 7,33 persen / tahun. Pertumbuhan pembangunan juga dapat di lihat dari banyaknya pembangunan perumahan, ruko, minimarket, maupun swalayan dan pasar- pasar tradisional di berbagai sudut kota (Padang dalam angka, 2018).

Permasalahan yang ada saat ini pusat perniagaaan terutama pusat perbelanjaan yang ada di kota Padang saat ini seluruhnya berada di kawasan Padang Barat, yaitu Plaza Andalas , SPR Plaza, Basko grand mall, Transmart (Daftar pusat perbelanjaan di Kota Padang, 2019). Sementara di bagian kota yang lain belum ada pusat perbelanjaan sehingga aktivitas dari pusat kota yang lain belum sepenuhnya dapat menampung kegiatan berbelanja bagi masyarakat kota Padang.

Setelah dilakukan pengamatan di lapangan, semua pusat perbelanjaan yang ada belum memiliki fasilitas tempat parkir yang nyaman dan memadai, sehingga kemacetan sering terjadi di depan pusat perbelanjaan. Kemacetan ini sanggat tidak nyaman bagi pengunjung yang hendak berbelanja sehingga sulit memarkirkan kendaraannya, hal ini sangat berpengaruh terhadap kegiatan berbelanja bagi masyarakat kota Padang.
Lokasi pusat perbelanjaan yang ada saat ini tergolong sempit sehingga tempat parkir yang ada kurang efektif bagi pengunjung yang hendak berbelanja, serta kurangnya area atau ruang promosi produk untuk menarik konsumen.

Berdasarkan RTRW pasal 28 UU No. 26/2007 tentang Penataan Ruang, salah satu peruntukan lahan yang diperbolehkan untuk pembangunan pusat perbelajaan terletak di kawasan By pass, khususnya daerah Cengkeh Berdasarkan permasalahan yang telah di paparkan di atas, maka perlu Perencanaan Pusat Perbelanjaan, yang memiliki lahan parkir yang memadai, untuk pusat perbelanjaan dilengkapi dengan area promosi produk yang ada di dalam negeri mau pun di luar negeri sehingga permasalahan yang ada dapat terealisasi dengan baik.

Menurut Rencana Teknis Ruang Kota (RTRK) Kawasan By pass ditetapkan sebagai daerah pengembangan Kota Padang yang berfungsi sebagai kawasan perdagangan, industri, jasa dan trasportasi. Kawasan By pass akan menjadi kawasan dengan tingkat pertumbuhan yang relative sangat cepat, karena lahan diperuntukan sebagai kawasan industri (industry park), kawasan pergudangan, perkantoran, perdagangan, jasa, serta pendidikan dan transportasi. Peruntukan lahan mampu mengundang para investor lokal maupun investor luar negeri untuk menanamkan modal di Kota Padang, tepatnya di kawasan By pass, sehingga mampu meningkatkan perekonomian masyarakat kota Padang.

Pusat perbelanjaan yang akan direncanakan merupakan wadah akomodasi berupa pusat perbelanjaan dengan area rekreasi yang lebih luas dan memadai bagi masyarakat kota Padang sehingga perencanaan pusat perbelanjaan yang di cangkan akan menjadi aikon baru di Kota 
Padang khususnya kawasan by pass yang terdampak lansung dari keberadaan pusat perbelanjaan yang di rencanakan.

\section{METODE PENELITIAN}

Metode penelitian yang digunakan pada perencanaan Pusat Perbelanjaan di Kota Padang yaitu penelitian kualitatif deskriptif yang mampu menangkap berbagai informasi kualitatif dengan deskripsi sesuai dengan informasi yang ada.

Data deskripsi yang diperoleh dilapangan berupa Data keadaan tempat parkir dan tempat pameran produk di Plaza Andalas, SPR Plaza, Basko Grand Mall dan Transmart.

Kondisi sekitar Site, Tanggapan pengunjung terhadap Plaza Andalas, SPR Plaza, Basko Grand Mall, dan Transmart.

Antusias masyarakat yang berbelanja Antusiasme masyarakat yang berbelanja di Plaza Andalas, SPR Plaza, Basko Grand Mall dan Transmart. Kualitas pelayanan di Plaza Andalas, SPR Plaza, Basko Grand Mall dan Transmart.

Pengumpulan data dilakukan dengan observasi dengan mengamati langsung objek pusat perbelanjaaan, dan wawancara yang dilakukan kepada pengunjung,

\section{PEMBAHASAN}

Pemilihan lokasi tapak gedung pusat perbelanjaan yang direncanakan dapat ditentukan berdasarkan beberapa kriteria dengan pertimbangkan sebagai berikut:

Luas tapak sesuai dengan kebutuhan pusat perbelanjaan peruntukan lahan sesuai dengan RT RK kota Padang

Aktifitas tapak relatif tidak padat, Pencapaian dan sirkulasi, Lahan yang luas dan strategis, dekat dengan fasilitas penunjang lainnya, dan Keadaan Fisik Tapak Perencanaan

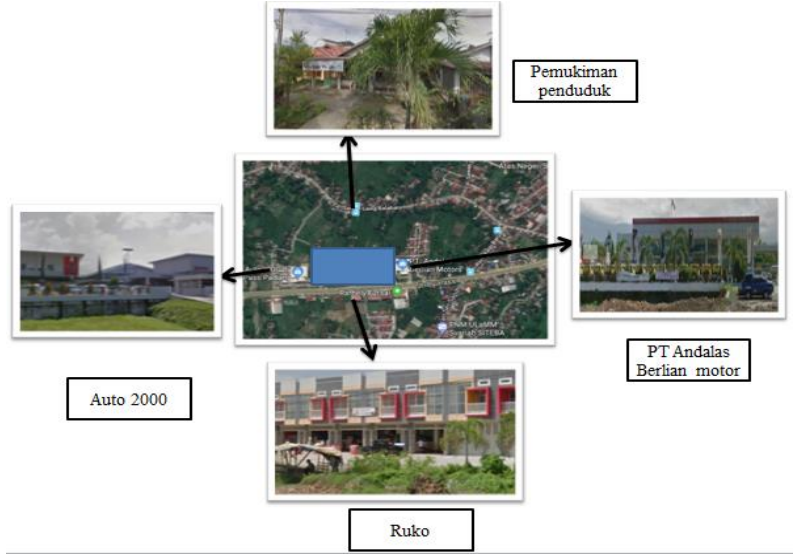

Gambar 1. Analisa Potensi Tapak

Tapak terletak di kawasan kuranji dengan luas 3 Hektar, dengan kontur tanah dari $10-15 \mathrm{~cm}$, Koefisien Dasar Bangunan (KDB) 70 - 90\%, dan Koefisien Lantai Bangunan (KLB) 0,8.

Kondisi fisik dan batasan tapak adalah sebagai berikut:

- Sebelah utara berbatasan dengan dialer mobil auto 2000

- Sebelah selatan berbatasan dengan PT Andalas Berlian Motor

- Sebelah timur berbatasan dengan lahan pertanian penduduk

- Sebelah barat berbatasan dengan ruko ruko.

Analisa Makro, orientasi Matahari Terhadap Site, Orientasi yang digunakan pada bangunan yang direncanakan yaitu menggunakan orientasi barat-timur agar pancaran sinar matahari dari arah timur dapat digunakan sebagai pencahayaan alami pada pagi hari dan dari arah barat dapat digunakan sebagai pencahayaan alami pada sore hari. 


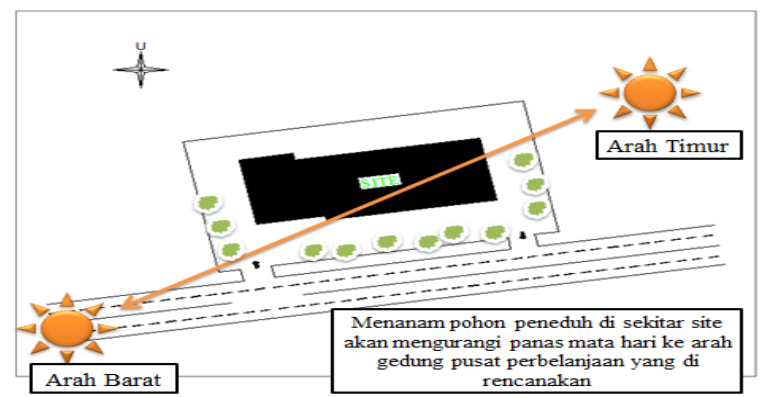

Gambar. 2. Analisa Matahari

Kebisingan pada Site, penambahan pohon sebagai filterisasi atau buffer terhadap jalan karena kebisingan kendaraan. Jenis tumbuhan yang efektif untuk meredam suara ialah yang mempunyai tajuk yang tebal dengan daun yang rindang (Grey dan Deneke dalam Richard Hauer, 2005). seperti pohon perdu, mahoni dan pinus, atau menggunakan pagar tertutup semak, dan meletakan massa bagunan agak jauh dari sumber kebisingan.

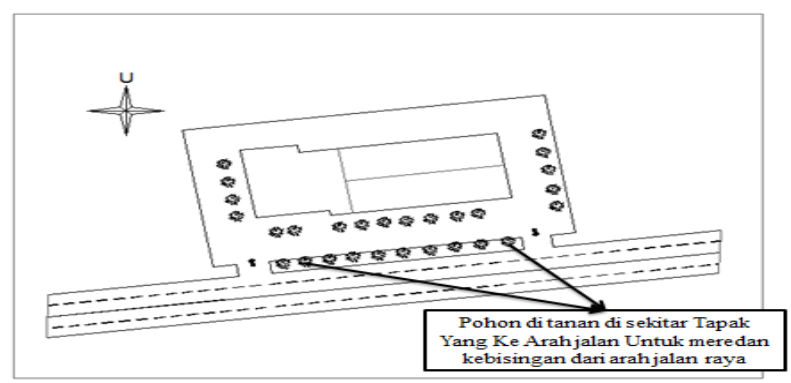

Gambar. 3. Analisa Kebisingan

Arah Angin, Menambahkan pepohonan di bagian barat site untuk mengurangi masa bangunan dari terpaan angin darat pada malam hari dan untuk menghalangi masa bangunan dari debu dan abu yang di berasal dari polusi kendaraan dan jalan. Membuat pemecah aliran angin pada massa bangunan seperti dengan membuat sudut-sudut tumpul pada bangunan.

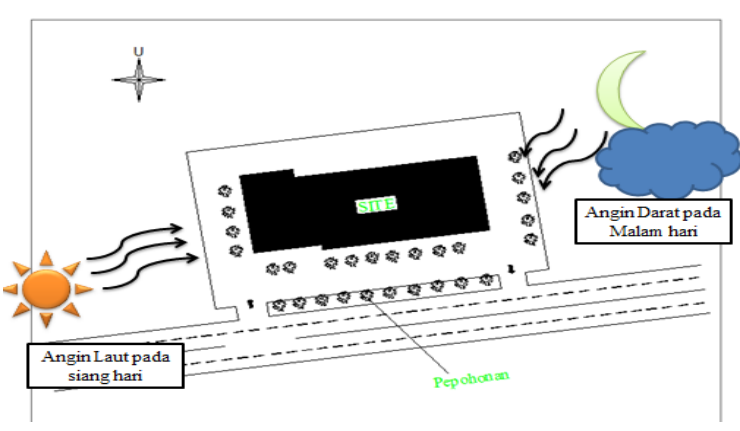

Gambar. 4. Analisa Arah Angin

Vegetasi pada Site, menambah vegetasi pada jalur pedestrian. Perletakan vegetasi disesuaikan dengan perletakan massa bangunan.

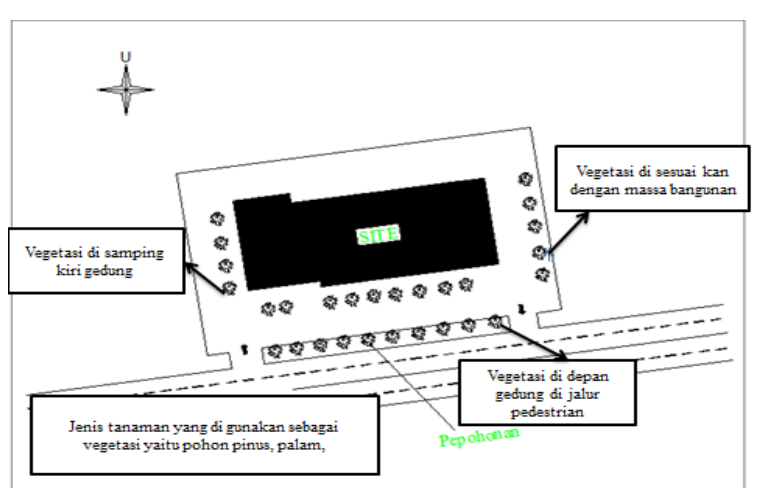

Gambar. 5 Analisa Vegetasi

Sirkulasi Site, Sirkulasi pada perencanaaan terdiri dari: sirkulasi Kendaraaan dan sirkulasi pejalan kaki. Membagi entrance menjadi 2 antara mobil dan motor. Memisahkan antara entrance dan exit menyediakan pedestrian/ trotoar menuju site. Membuat jalur khusus pejalan kaki untuk entrance dan exit.

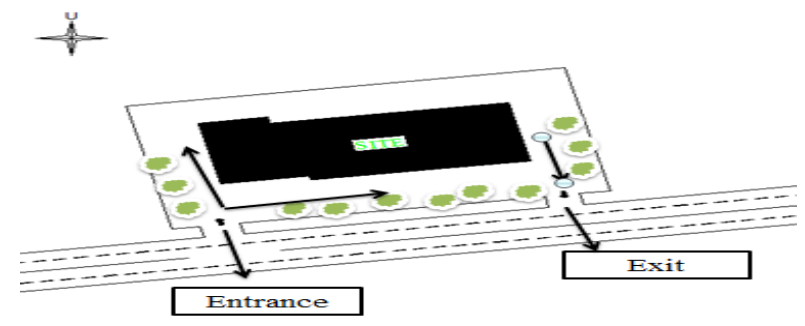

Gambar. 6. Analisa Sirkulasi 
View Site, Menempatkan point of interest (titik tangkap / daya tarik) pada salah satu bagian massa bangunan. View/arah hadap bangunan yaitu mengarah ke jalan sesuai dengan susunan rumah masyarakat minang. Fasade bangunan dirancang selaras dengan keadaan disekitar site dengan dukungan perbukitan pertanian.

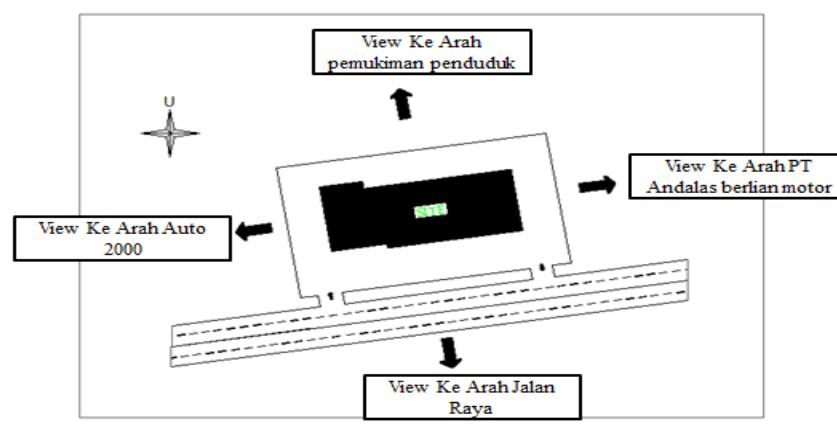

Gambar. 7. Analisa View

Sistem Parkir Kendaraan Dalam Site. Pola parkir lurus sejajar, area yang tidak ekonomis tapi mudah dalam pengaturannya. Pemilihan pola parkir, pola parkir 90 derajat karna (a) Kapasitas parkir cukup banyak, (b) Ruang belok kendaraan tidak besar (c) Tidak dapat di gunakan sirkulasi dua arah

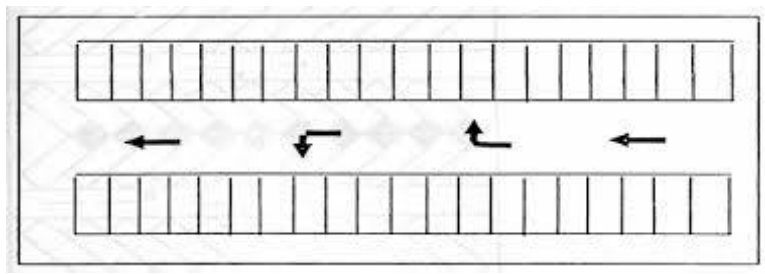

Gambar 8 Model Parkir 90

Penzoningan, Pembagian zona pada perencanaaan ini terdiri dari Zona semi publik yaitu: Toko Retail, Kafe, Foodcourt, KFC JCO, A\&W, PIZZA HUT, Hypermart, Matahari departemen store.

Zona privat yaitu: Bioskop, Kantor pengelola, Zona publik yaitu: Toko dealer disply ,Games Center , area pameran taman

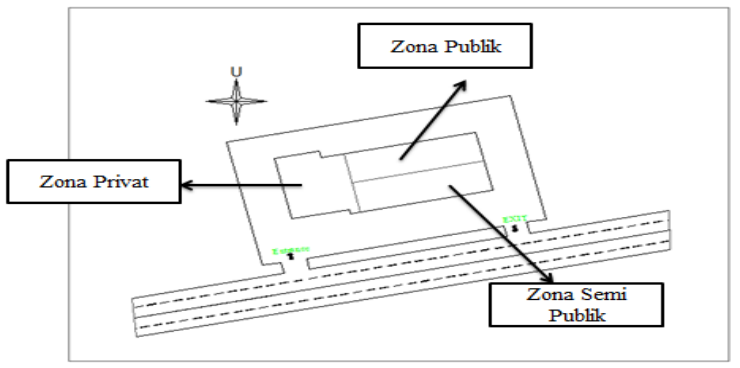

Gambar. 9. Analisa Penzoningan

Analisa Mikro

Tabel 1. Aktivitas dan Kebutuhan Ruang

\begin{tabular}{|l|l|}
\hline $\begin{array}{l}\text { Jenis } \\
\text { aktivitas }\end{array}$ & Kebutuhan ruang \\
\hline $\begin{array}{l}\text { Perniagaan } \\
\text { produk } \\
\text { perdagangan }\end{array}$ & $\begin{array}{l}\text { Toko retail type A } \\
\text { Toko retail type B } \\
\text { Toko retail type C } \\
\text { Matahari Departemen Store } \\
\text { Hypermart }\end{array}$ \\
\hline $\begin{array}{l}\text { Tempat } \\
\text { rekreasi } \\
\text { keluargga }\end{array}$ & Taman rekreasi keluargga \\
\hline $\begin{array}{l}\text { Promosi } \\
\text { pameran } \\
\text { produk }\end{array}$ & Hall \\
\hline Hiburan & $\begin{array}{l}\text { Bioskop } \\
\text { Ruang proyektor film } \\
\text { Loket bioskop } \\
\text { Wc bioskop } \\
\text { Pusat permainan }\end{array}$ \\
\hline $\begin{array}{l}\text { Indonesia foodcourt } \\
\text { pusat }\end{array}$ & $\begin{array}{l}\text { Internasional foodcourt } \\
\text { Wc \& wastafel foodcourt } \\
\text { KFC } \\
\text { WC \& wastafel } \\
\text { JCO Donuts dan coffe } \\
\text { A \& W } \\
\text { WC \& wastafel } \\
\text { Kafe Vitoria } \\
\text { WC \& wastafel }\end{array}$ \\
\hline $\begin{array}{l}\text { Tempat parkir mobil } \\
\text { Tempat parkir motor } \\
\text { Tempat } \\
\text { pengangkut logistik }\end{array}$ \\
$\begin{array}{l}\text { Ruang direktur utama } \\
\text { Ruang manager kepala devisi }\end{array}$ \\
\hline
\end{tabular}




\begin{tabular}{|c|c|}
\hline & $\begin{array}{l}\text { pemasaran } \\
\text { Ruang staf pengadaan \& } \\
\text { pengolahan } \\
\text { Ruang staf ME } \\
\text { Ruang staf keamanan \& } \\
\text { kebersihan } \\
\text { Ruang rapat } \\
\text { Workshop } \\
\text { Pusat informasi } \\
\text { Ruang cetak } \\
\text { Ruang arsip } \\
\text { Loading dock \& gudang } \\
\text { Ruang genset } \\
\text { Ruang mesin AC sentral } \\
\text { Ruang pompa air } \\
\text { Ruang computer } \\
\text { Wc }\end{array}$ \\
\hline Shalat & $\begin{array}{l}\text { Mushola } \\
\text { Wc mushola } \\
\text { Tempat wudhu }\end{array}$ \\
\hline $\begin{array}{l}\text { Beristirahat } \\
\text { \& menunggu }\end{array}$ & $\begin{array}{l}\text { Rest \& waiting area } \\
\text { Wc \& wastafel }\end{array}$ \\
\hline \multicolumn{2}{|l|}{ Buang air } \\
\hline $\begin{array}{l}\text { Transfer / } \\
\text { mengambil } \\
\text { uang }\end{array}$ & $\begin{array}{l}\text { Bank } \\
\text { ATM Center }\end{array}$ \\
\hline $\begin{array}{l}\text { Menjaga } \\
\text { keamanan } \\
\text { pusat } \\
\text { perbelanjaan }\end{array}$ & Ruang security \\
\hline Merokok & Smoking room \\
\hline $\begin{array}{l}\text { Transit } \\
\text { kendaraan } \\
\text { umum }\end{array}$ & Tempat transit kendaraan \\
\hline
\end{tabular}

Sumber: Analisa Pribadi

Konsep Desain, Tema yang digunakan pada Perencanaan Pusat Perbelanjaan di Kota Padang adalah Green Arsitektur. Dirancang untuk mengurangi dampak lingkungan bangunan terhadap kesehatan manusia dan lingkungan alami dengan melalui (a) Bentuk dan orientasi bangunan: dibuat memanjang dimana didepan bangunan dibuat taman yang membuat sejuk dan nyaman, (b) Shading \& Reflektor: shading light shelf untuk mengurangi panas yang masuk ke dalam gedung namun tetap memasukan cahaya dengan efisien (c) Sistem Penerangan: sistem penerangan dalam bangunan menggunakan intelegent lighting system yang dikendalikan oleh main control panel sehingga nyala lampu dimatikan secara otomatis oleh motion sensor \& lux sensor, (d) Water recycling system: water recycling system berfungsi untuk mengolah air kotor dan air bekas sehingga dapat digunakan kembali untuk keperluan flushing toilet ataupun sistem penyiraman tanaman.

\section{Konsep Organisasi Bangunan dapat dilihat sebagai berikut,}

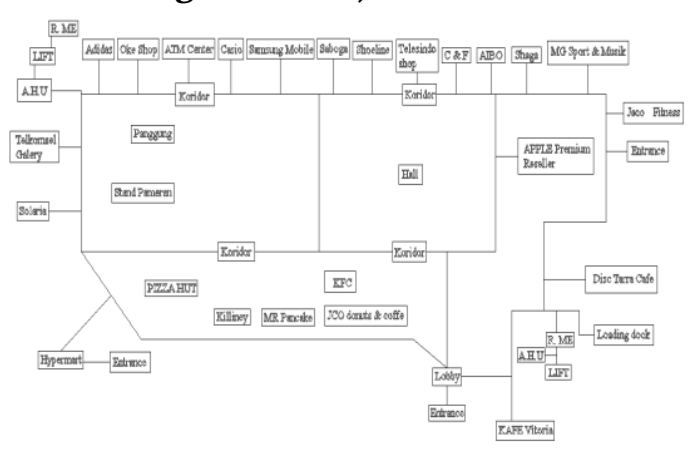

Bagan 1 Organisasi ruang Pusat perbelanjan Lantai 1

(Sumber: Pengolahan Data)

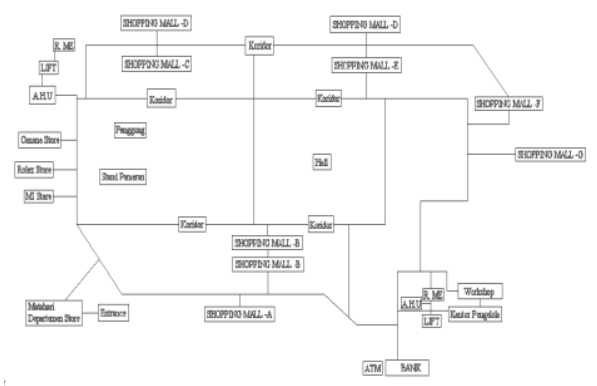

Bagan 2 Organisasi ruang Pusat perbelanjan Lantai 2

(Sumber: Pengolahan Data)

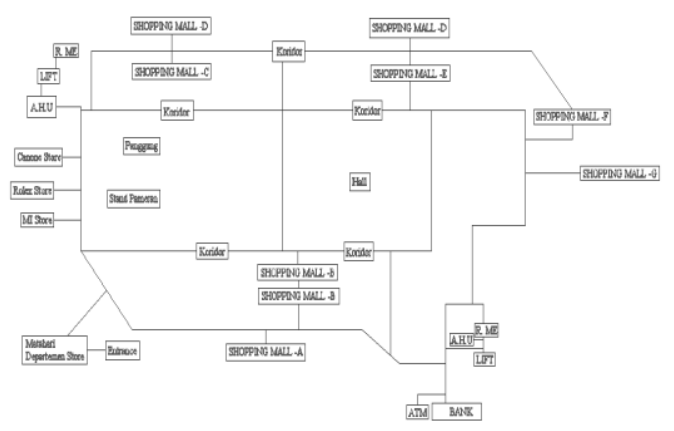

Bagan 3 Organisasi ruang Pusat perbelanjan Lantai 3

(Sumber: Pengolahan Data) 


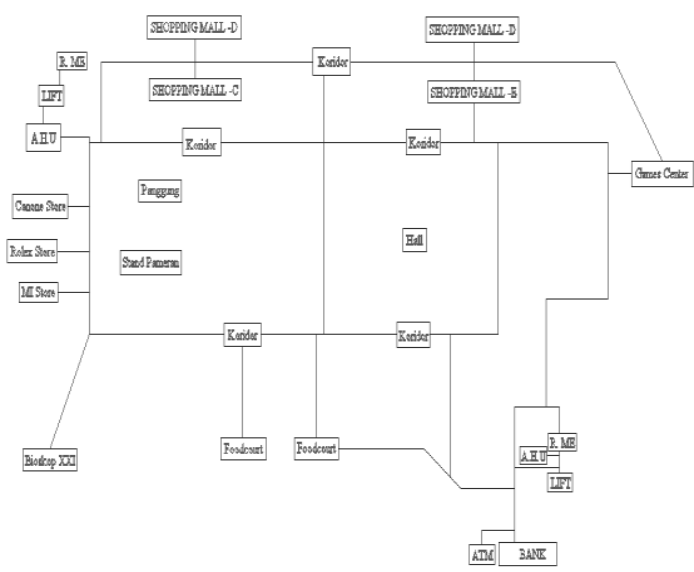

Bagan 4 Organisasi ruang Pusat perbelanjan Lantai 4

(Sumber: Pengolahan Data)

Konsep Bentuk, Bangunan pusat perbelanjaan yang direncanakan terdiri satu massa bangunan dengan bentuk denah bangunan mengadopsi empat persegi panjang.

Konsep tekstur dan Warna, Warna yang digunakan pada gedung adalah warnawarna yang dapat menimbulkan semangat, dramatis, tenang, sejuk, tidak membosankan dan terutama memberikan kesan nyaman kepada pengunjung, yaitu: warna coklat, merah, hitam, kuning, putih, hijau, dan abuabu.

\section{Konsep Mekanikal dan Elektrikal,} Konsep mekanikal dan elektrikal yang digunakan adalah (a) Penghawaan; memakai sistem penghawaan buatan dan alami. Untuk sistem penghawaan buatan hanya pada ruang toko, tempat kuliner, bioskop, hypermart, games center, dan kantor pengelola, sedangkan di sepanjang koridor dan tempat smoking area memanfaatkan penghawaan alami (b) Transfortasi bangunan; menggunakan transfortasi vertical dengan menggunakan Lift, escalator, dan tangga darurat (c) Instalasi listrik; sumber dari PLN dan Solarsel

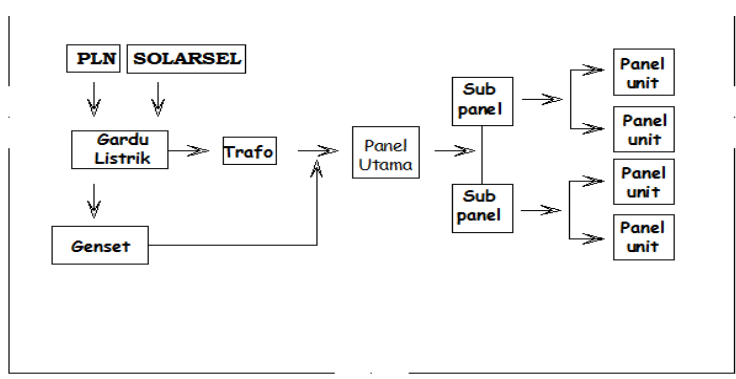

Bagan 5. Sistem Jaringan Listrik (Sumber: Pengolahan Data)

\section{Jaringan Telepon}

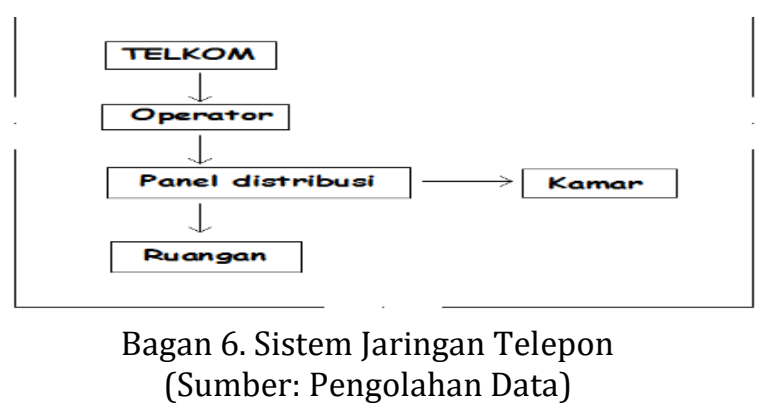

Sistem Penangkal Petir, Pengamanan bangunan pusat perbelanjaan menggunakan sistem penagkal petir Faraday (Sepannur, 2012).

Sistem Pemadam Kebakaran, Menurut Tomi Suroto (2011), sistem pemadam kebakaran dilengkapi dengan emergency exit sebagai sarana fire protectiont, sistem selang air bertekanan (hydrant system), dan sistem selang air bertekanan (hydrant system)

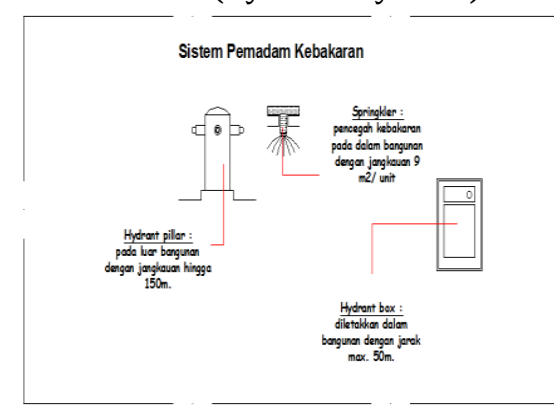

Bagan 7. Sistem Pemadam Kabakaran (Sumber: Pengolahan Data)

Utilitas Dalam Bangunan, Sistem utilitas pada bangunan terdiri dari sistem air 
bersih dan air kotor dijelaskan bagan berikut:

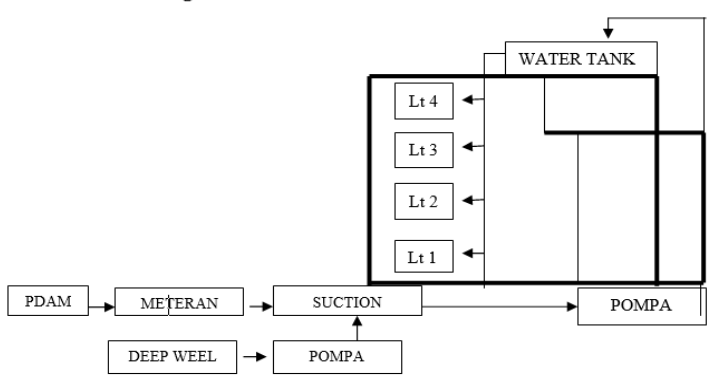

Bagan 8. Sistem Air Bersih

(Sumber: Pengolahan Data)
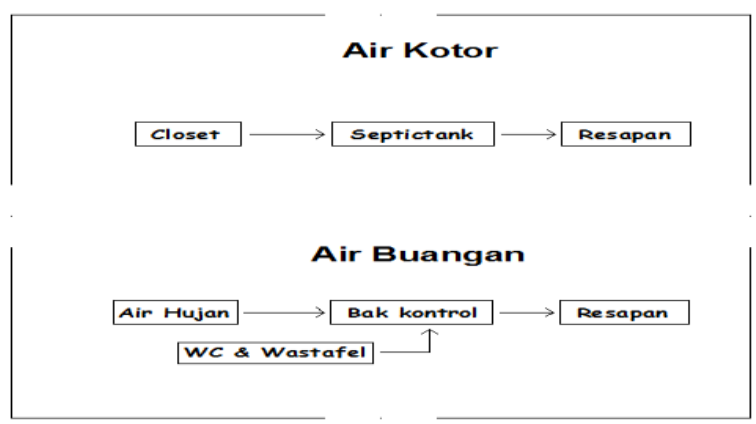

Bagan 9. Sistem Pembuangan Air Kotor

(Sumber: Pengolahan Data)

Konsep Struktur, Pondasi yang dipakai pada pembangunan pusat perbelanjaan adalah pondasi tiang pancang dengan pertimbangan sesuai dengan keadaan tanah di sekitar site. Sedangkan untuk struktur tengah memilih sistem balok induk dan balok anak dengan sistem grid sesuai dengan bentangan bangunan yang besar. Struktur atas pada pembangunan pusat perbelanjaan yaitu menggunakan struktur rangka baja.

\section{SIMPULAN}

Desain dari perencanaan ini berupa sebuah pusat perbelanjaaan dengan konsep Green Arsitektur yang memenuhi kebutuhan masyarakat baik dari kebutuhan berbelanja dan kebutuhan refresing.

\section{DAFTAR PUSTAKA}

F.D Ching, Arsitektur bentuk, Ruang dan Tatanan. Ciracas: Penerbit Erlanga, 2008. Haryadi dan B.Setiawan, Arsitektur, Lingkungan, dan Perilaku, Yogyakarta: Gajah Mada University Press, 2010.

J.S Juwana, Paduan Sistem Bangunan Tinggi. Ciracas: Penerbit Erlanga, 2005.

M Karlem, Dasar-dasar Perencanaan Ruang. Ciracas: Penerbit Erlanga, 2007.

Kuranji B (n.d) Daftar pusat perbelanjaan di Padang

Neufert and Ernst, Data Arsitek jilid I Edisi 33, Terjemahan Sunarto Tjahjadi. Jakarta : Erlangga, 1996.

Neufert and Ernst, Data Arsitek jilid II Edisi 33, Terjemahan Sunarto Tjahjadi. Jakarta : Erlangga, 1996.

Padang, B.P.S.K, Kota Padang Dalam Angka In BPS Padang, 2018.

Presiden RI 2014 Undang-Undang RI Nomor 36 Tahun 2014 tentang Tenaga Kesehatan Presiden Republik Indonesia

Sepannur Bandri, Perancangan Instalasi Penangkal Petir Eksternal Gedung Bertingkat (Aplikasi Balai Kota Pariaman), 2012.

Suroto T, Sistem Pemadam Kebakaran, 2011. 